\title{
Children's Economic and Social Rights and Child Poverty: The State of Play
}

\author{
Aoife Nolan \\ School of Law, University of Nottingham, Nottingham, UK \\ Aoife.Nolan@nottingham.ac.uk \\ Kirrily Pells \\ UCL Institute of Education, London, UK \\ k.pells@ucl.ac.uk
}

\begin{abstract}
This article focuses on both economic and social rights (ESR) and child poverty. In doing so, it identifies and considers key developments and gaps in child rights scholarship (CRS) in these areas. The authors' treatment of these issues together is logical (albeit certainly not inevitable) given the strong connection between ESR and poverty. Both are areas which have been under-explored in CRS: ESR have been historically under-theorised and marginalised in child rights research, whereas child poverty is an area that has received extensive academic attention but only a limited amount of this has been from a child rights perspective.

The article begins by outlining the state of the existing theoretical child rights literature on ESR, before going on to consider the growing body of CRS focused on specific ESR-thematic areas. The authors make clear the historic dominance of law in terms of child ESR scholarship while flagging the increasing ESR-focused/framed work emerging from other disciplines, arguing that this is evidence of an ever-wider and more multidisciplinary engagement with ESR. Moving on to the topic of child poverty, the authors note that, with some notable exceptions, there has been a failure on the part of child rights scholars to engage with child poverty, a fact that is at least partially attributable to disciplinary disconnects: while CRS (and ESR scholarship in particular) has come to be dominated by lawyers to a large degree, much academic work on child poverty originates in economics, development studies and social policy. There is, however, some recognition by child poverty scholars (and more so by practitioners) that child poverty is a "child rights" issue, albeit that there is an ongoing failure on the part
\end{abstract}


of child poverty scholarship to really come to terms with the complexities of child rights in terms of the implications of such for the definition and measurement of child poverty. The authors conclude by flagging future avenues for academic engagements with child ESR and child poverty, considering both the ways in which existing scholarship may be enriched as well as the potential dangers that new directions may pose in terms of child ESR specifically.

\section{Keywords}

child rights - child poverty - economic and social rights - socio-economic rights human rights - Sustainable Development - citizenship - multidimensional poverty income poverty - social justice - budgets - economic policy - children's rights SDGS

\section{Introduction}

This article will focus on both economic and social rights (ESR) and child poverty. In doing so, it will focus on key developments or gaps in child rights scholarship (CRS) in these areas. The authors' treatment of these issues together is logical (albeit certainly not inevitable) given the strong connection between ESR and poverty. ${ }^{1}$ Both are areas which have been under-explored in CRS: ESR have been historically under-theorised and marginalised in child rights research, whereas child poverty is an area that has received extensive academic attention but only a limited amount of this has been from a child rights perspective.

The article begins by outlining the state of the existing theoretical child rights literature on ESR, before going on to consider the growing body of CRS focused on specific ESR-thematic areas. The authors make clear the historic dominance of law in terms of child ESR scholarship while flagging the increasing ESR-focused/framed work emerging from other disciplines, arguing that this is evidence of an ever-wider and more multidisciplinary engagement with ESR. Moving on to the topic of child poverty, the authors note that, with some notable exceptions, there has been a failure on the part of child rights scholars to engage with child poverty, a fact that is at least partially attributable to

1 That is not to ignore the relationship between poverty and other child rights. See, e.g., UNICEF 2005; OHCHR 2012). 
disciplinary disconnects: while CRS (and ESR scholarship in particular) has come to be dominated by lawyers to a large degree, much academic work on child poverty originates in economics, development studies and social policy. There is, however, some recognition by child poverty scholars (and more so by practitioners) that child poverty is a "child rights" issue, albeit that there is an ongoing failure on the part of child poverty scholarship to really come to terms with the complexities of child rights in terms of the implications of such for the definition and measurement of child poverty. The authors conclude by flagging future avenues for academic engagements with child ESR and child poverty, considering both the ways in which existing scholarship may be enriched as well as the potential dangers that new directions may pose in terms of child ESR specifically. ${ }^{2}$

\section{$2 \quad$ Mind the Gap: Theoretical Perspectives on Child ESR}

ESR are those rights that deal with minimum conditions for welfare and wellbeing (Veerman, 1992: 25). Despite the centrality of ESR to children's flourishing as children in the short-term and as adults in the longer term, they have received relatively little attention within the very extensive literature on children's rights (Nolan, 2011). There has been some work on theorising child ESR through, for instance, the employment of the capabilities approach (see, e.g., Peleg, 2013; Dixon and Nussbaum, 2012) or in terms of interests and will theory of rights or variants thereof (see, e.g., Liebel, 2018; MacCormick, 1976; Feinberg, 1976; Hollingsworth, 2013). Still, this is a small body of work relative to the overall scholarship focused on critiquing traditional assumptions regarding the ontology of the child, such as competence, capacities and the implications of such for children's resultant status as (non)rights-holders in terms of different theories of rights (for a useful overview, see Freeman, 2011). Furthermore, while there is considerable work on the status of ESR as rights in terms of moral rights theory (see, e.g., Sadurski, 1986; Cranston, 1973; Fabré, 200o; Bilchitz, 2007; Griffin, 2008) or in the context of theories of justice (see, e.g., Waldron, 2011), this has not addressed children's rights to any meaningful degree.

Child rights theorists, perhaps unsurprisingly, have concentrated much of their attention on the conceptualisation and justification of those rights that

2 It should be noted that this review of child ESR and child poverty literature is inevitably incomplete due to the authors' linguistic limitations. Given that some of the most expansive child ESR standards and significant case-law originates in Latin American jurisdictions, including Colombia, Brazil and Argentina, it is a serious shortcoming of this article that it does not engage with the non-English academic literature related to these domestic experiences. 
are most controversial in terms of traditional understandings of children - for instance, rights closely related to the exercise of autonomy (e.g., participation rights). ${ }^{3}$ This contrasts with the relative neglect of theoretical work focused on those rights that can be more directly viewed as corresponding to (apparently) uncontroversial needs and/or interests, the satisfaction of which is commonly regarded as necessary for ensuring child survival and development. Such rights can be viewed as relatively unchallenging in terms of paternalistic or welfare attitudes towards children (see, e.g., Brighouse, 2002). The under-theorisation of children's ESR is consistent with the under-theorisation of ESR under international human rights law scholarship, ${ }^{4}$ where recourse is often had to vaguely defined concepts of dignity or personhood as the basis of right-holder status. ${ }^{5}$ This latter under-theorisation has undoubtedly contributed to the conceptual doubts that have historically operated to undermine ESR under international human rights law (IHRL) and beyond - in terms of the status of ESR as rights imposing binding obligations, their scope and content, and the appropriate mechanisms for their legal and political enforcement. It can be assumed that under-theorisation has played a similar role in a child rights-specific context.

\section{Child ESR Scholarship: From the Legal to the Multi-disciplinary}

Moving beyond the theoretical literature, existing child ESR scholarship is predominantly academic work focused on fleshing out child rights standards in the context of specific ESR or ESR-related areas. This includes work on the right to health (see, e.g., Spronk-van der Meer, 2014; Tobin, 2019; Reinbold, 2014), the right to food (Ó Cathaoir, 2017), the rights to social security and social protection (see, e.g., O'Brien, 2019; Simpson, 2018; Sloth-Nielsen, 2001; Langford

3 In their 2009 review of children's literature since the adoption of the UNCRC, Reynaert et al. described 'autonomy and participation rights as the new norm in children's rights practice and policy' (Reynaert et al., 2009: 518). The same remains largely true today. It is thus perhaps unsurprising that some of the more interesting work around the theorisation of children as ESR-bearers is in the context of children's economic rights and engagement in work and work-related activities that are regarded as associated with adulthood in many national contexts. For more, see Hanson and Vandaele, 2013; Liebel, 2020 (forthcoming).

4 It should be noted that this dearth of literature on the theoretical underpinnings and justifications of ESR stands in sharp contrast to the very extensive body of literature on the scope/ content of ESR and the obligations such rights impose.

5 For a discussion of the incompletely theorised nature of international human rights law more generally, including the CRC, see Tobin, 2013. For notable exceptions to the nontheorisation of ESR and ESR obligations under IHRL, see Shue, 1996; Young, 2008; Waldron, 2014, and Warwick, 2019. 
and Khaliq, 2019), the right to survival and development (Mahgoub, 2015; Peleg, 2019), the right to an adequate standard of living (Nolan, 2019; Redmond, 2008; Eide, 2006) the right to play (see, e.g., Lott (forthcoming); Lansdown and Tobin, 2019), work rights/child labour (Liebel, 2015; Alston, 2019), and the right to education and aims of education (Veryheyde, 2008; Lundy and Tobin, 2019; Zinga and Young, 2008). Predictably, given the linkage between discrimination and the failure to secure ESR, academic work focused on socially vulnerable, marginalised and disadvantaged groups of children has often had an ESR component (see, e.g., Byrne, 2019 on disabled children; Pobjoy, 2019, Smyth, 2018, and Ceriani Cernadas, 2015 on refugee/migrant children; Mwambene, 2016 and Croll, 2007 on girls; Kange'the and Nyamutinga, 2016 on street-connected children and child-headed households). Indeed, this academic approach is consistent with that of the Committee on the Rights of the Child, which - in addition to recognising the particular vulnerability of poor children with regard to rights enjoyment - has repeatedly emphasised the particular vulnerability to poverty and deprivation of some groups of children (Vandenhole, 2014; Nolan, 2018).

Unsurprisingly given the central role played by the CRC in CRS post 1989, a significant majority of child ESR research takes that instrument as its central framework. There is no doubt, however, that the relatively limited engagement of the Committee on the Rights of the Child with ESR under the CRC (Nolan, 2013) until the early 2010 s did not serve to encourage scholarly engagement with ESR under the CRC. Indeed, this lack of engagement seems at least partially to blame for the existence of child-specific ESR scholarship that relies heavily on the non-child-specific ESR framework of the International Covenant on Economic, Social and Cultural Rights when considering the scope of ESR obligations in a child-specific ESR context (see, e.g., Apodaca, 2010). Furthermore, while child rights are sometimes addressed by ESR scholars, this has generally been in a passing way, with very limited attention focused on the specific position of children as right-holders and no meaningful theorisation of child ESR.

While there was a very slow start in terms of scholarship on child ESR, there is no doubt that there has been a notable increase in such work, particularly since the entry of ESR into "the academic mainstream" in the 2000s. Consistent with the ever-growing body of child rights-specific jurisprudence at the regional level - a key feature of which has been increasing engagement with the CRC and child $E S R$ - we are seeing a small but developing body of scholarship focused on ESR under specific regional systems (see, e.g., Sloth-Nielsen, 2016; De Paz González, 2018: 92-122; Nolan and Kilkelly, 2016; Chirwa, 2016; Durojaye, 2012; Odongo, 2012). There is also extensive academic work around children 
under domestic ESR frameworks (see, e.g., Veriavaa and Skelton, 2019; O'Mahony, 2006; Rebell, 2019; O'Brien, 2019; Etchichury, 2018; Lopes et al., 2017; Bestard, 2012, Gray, 2011), ${ }^{6}$ in the context of child law, constitutional law, health law, social security law, youth justice, and education law.

There remain, however, shortcomings in terms of child rights scholars' treatment of child ESR due to relatively frequent misunderstanding of the obligations imposed by those rights. This is attributable at least in part to the relative complexity of ESR obligations as well as to the relative neglect of such in human rights and child rights scholarship and course curricula. That said, there has been slow but definite progress in fleshing out those obligations (see, e.g., Nolan, 2013 and 2018; Tobin, 2019; Vandenhole, 2009). This has stimulated, fed into and complemented work on the part of the Committee on the Rights of the Child in the area (see. e.g., UN Committee on the Rights of the Child 2016). There are still gaps in ESR scholarship in terms of addressing the parameters of the CRC framework: for instance, the scope of extra-territorial obligations and non-state actor obligations. (Notable exceptions on the former point include Vandenhole, 2009; Nyongesa Wabwile, 2010, while Gerber et al., 2013 have written on the latter one.) That said, there is no reason to assume that these lacunae will not be addressed as child ESR scholarship evolves and its profile increases.

In terms of child rights research scholarship, there are some limited examples of employment of ESR as frameworks for child rights research methodology (e.g., Larkins, 2013). In practice, however, much of this work does not employ an ESR framework as such, rather it entails a methodology premised on participation-related CRC obligations in ESR-related contexts such as education (e.g., Lundy, 2007; Alasuutari, 2014; Pettersson, 2013) or health (e.g., Reading et al., 2008), in some instances to the extent of excluding any reference to relevant ESR. ${ }^{7}$

Currently, the area of child ESR is dominated by lawyers or those with a legal background - something that would seem to reflect the "legal" focus of child rights as manifested in the CRC. Positively from the perspective of the development of an inter and/or multi-disciplinary body of research on child ESR, there is some evidence of scholarship "beyond the law" in this area, with increasing

6 It should be noted that there is extensive child constitutional and legislative social rights jurisprudence from the Americas but, due to linguistic limitations on their part, the authors are not able to provide a full account of the Spanish and Portuguese academic literature pertaining to the relevant national frameworks and case law.

7 See, e.g., the non-reference to Article $31, \mathrm{CRC}$ in the context of a piece on child rights and play in Yates and Oates, 2019. 
references to child ESR standards and obligations being made by those working in areas such as public health (e.g., Garde et al., 2017; Sanghera et al., 2015; O'Hare et al., 2018; Handsley and Reeve, 2018); education (e.g., Christie, 2010; McGrath, 2018); child protection and social work (e.g., Berthold and Libal, 2016; Dickinson, 2018); development economics (Reed et al., 2013); geography (e.g., Matthews and Limb, 1999); urban planning (e.g., Riggio, 2002), and philosophy (Bruno and Schweiger, 2019). This suggests a growing and increasingly multidisciplinary engagement with ESR. Overall, however, the ESR of children undoubtedly remains a neglected area of child rights at the international, regional and domestic levels compared to topics such as juvenile justice, violence against children or child participation rights.

Bridging Child Poverty and Children's Rights

Child poverty is certainly not solely an ESR issue ${ }^{8}$ but it has a particularly strong relationship with ESR. It is thus perhaps to be expected that the lack of scholarly focus on ESR has translated to some degree into child poverty, receiving less attention from child rights scholars - particularly lawyers. Indeed, the authors would argue that the disconnect between child poverty and child rights is attributable to disciplinary disconnects and the dominance of child poverty scholarship (particularly with regard to child poverty definition and measurement) by non-law disciplines such as development economics, and social policy. These disciplines bring huge conceptual and methodological strengths to bear in child poverty work but they do not necessarily (or even frequently) share the same aims, terminology, theoretical or methodological approaches as child rights academics; indeed, even those fields within children's rights studies have their own specificities, on epistemological, empirical, and institutional levels (Moody and Darbelly 2019: 12).

It is an oft-repeated truth that the CRC does not contain a specific right to freedom from poverty. In recent years, however, the Committee on the Rights of the Child has focused extensively on poverty, using the right to an adequate standard of living under Article 27 as a particular focus for its work in this area (Nolan, 2018). However, as Vandenhole (2014: 612) notes, 'the relationship between human rights of children and poverty is conceptually vague and in need of further clarification'. Child poverty can be approached as both a cause or consequence of ESR violations and there is no equivalent to the OHCHR's $(2004,2006)$ conceptual framework on human rights and poverty reduction for

8 See note 2, supra. 
child poverty and rights. That said, there are also growing efforts to conceptualise child poverty itself from an ESR perspective (e.g., Pemberton et al., 2007), including by lawyers (see, e.g, Nolan, 2011 and 2020 (forthcoming); Vandenhole, 2014), together with some recognition by non-legal child poverty scholars (and practitioners) that child poverty is a "child rights" issue (White et al., 2002; Gordon et al., 2003; Redmond, 2008). Unfortunately, there remains an ongoing failure really to come to terms with complexities of child rights in terms of requirements of standards of employment of those standards in both defining child poverty (though this is improving) and methodologies for measuring child poverty.

\section{$5 \quad$ Contested Concepts, Definitions and Measures}

In the wider, non-legal academic and policy literature on poverty (whether child or adult), debates on concepts/definitions and measurement are inextricably linked (Roelen et al., 2009). Within economics and, to some extent, social policy, data-driven approaches are typically employed, which means that the availability of data (either what data exist or choices over what it is deemed possible, desirable or appropriate to collect) drives the measure and thus the ways in which poverty is conceptualised and defined - although this approach is not without critique (see, e.g., Flaherty et al., 2004). Hence in the discussion that follows we explore both debates on concepts/definitions and measures of child poverty, considering the reasons for the lack of engagement of scholars from the child poverty field with children's ESR, as well as the strengths and challenges brought by engagement with other disciplines.

Poverty is typically conceptualised in either monetary or multidimensional terms (Roelen, 2010). Definitions of monetary poverty relate to income or expenditure in relation to absolute or relative standards. Absolute or extreme poverty is usually defined and measured as households living below a poverty line, such as the World Bank's threshold of living on less than \$1.9o dollars a day which has been applied in low and middle-income countries (World Bank, 2018) and included as an official indicator in the Sustainable Development Goals. Children living in such households are defined as living in absolute or extreme poverty (World Bank and UNICEF, 2016). In contrast, definitions of relative poverty acknowledge that living costs differ by context and that the circumstances of the individual must be judged in relation to others within the same society (see, e.g. Bradshaw et al., 2012). Again, relative poverty is typically measured in monetary terms, as it is argued income largely determines the extent to which an individual can participate in, or is excluded from, society. 
However, reliance on income-based definitions and measures of poverty is problematic from a children's rights perspective. First, children are often invisible when poverty is defined and measured in monetary terms, obscured by a focus on the family or household (as White et al., (2002: 383) note: 'incomepoverty data refer to the number of children living in poor households, rather than the number of children living in poverty'). Second, household-based income poverty measures assume an equal sharing of resources within the household, yet these may be allocated differently, between adults and children, between males and females, and so on (White et al., 2002; Hulme and McKay, 2008; Rodriquez Takeuchi, 2015). Third, while there have been attempts to disaggregate poverty data by age, these are only relatively recent and at first were not always consistent with the CRC in terms of that instrument's definition of a child (Olinto et al., 2013). Finally, while income is undoubtedly crucial, it may not be the key factor determining poverty in all societies (Penn, 2005); there are other material deprivations that might affect children more directly than monetary poverty, such as access to water, health services, schools and transport (Feeney and Boyden, 2004).

An alternative approach to conceptualisation and measurement, is to approach poverty as multidimensional, as advanced by the pivotal work of sociologist Peter Townsend (2009). He linked multiple deprivations (e.g. nutrition, education, health) with the human rights framework so as to include within the definition of poverty aspects such as exclusion from participation in everyday life and activities normal for the surrounding society (for instance, holding or attending ceremonies for rites of passage or attending activity clubs). Here, poverty is conceptualised as a denial of choices and opportunities due to a lack of resources that leads to social exclusion. ${ }^{9}$ For instance, the view of poverty as multidimensional is reflected in Sustainable Development Goal 1 with its reference to 'poverty in all its forms. ${ }^{10}$ It has been argued that a multidimensional approach aligns more closely with both a child-focused and a more holistic, rights-based approach by recognising the multiple and interconnected domains of people's lives that are affected by poverty (see, e.g., Pemberton et al., 2012). However, this is still dependent on how material deprivation is defined and the main multidimensional indices - such as the UN Human Development Index (HDI) which ranks countries on "progress" in the dimensions

For an interesting example of an exploration of the relationship between child rights, poverty and social exclusion as separate concepts, in the context of an argument that the adoption of particular constructions of children's rights in policy and practice might result in social exclusion, see Reynaert and Roose, 2016.

10 While the definition of poverty goes beyond income alone, the underlying target references national definitions of poverty, which could still be income related. 
of health (e.g. life expectancy), education (e.g. expected years of schooling for children) and material living standards (e.g. gross national income per capita), and the Multidimensional Poverty Index (MPI) (which uses the same three dimensions, but with a broader range of indicators) - have limited direct measures that capture child-specific data (White et al., 2002).

Specific child-level multidimensional poverty indices have been created that attempt to address some of the shortcomings identified above. Two out of the three most common approaches to measuring child multidimensional poverty use the UNCRC as a foundation. The "Bristol Approach" created for UNICEF's (2007) Global Study on Child Poverty has seven dimensions, which the creators argue map onto Articles of the UNCRC (see Gordon and Nandy, 2012a; Pemberton et al., 2012: 33) and categorises a child as "poor" if they are deprived in two or more dimensions (which have moderate and severe thresholds). The MODA approach (Multiple Overlapping Deprivations Analysis MODA) also developed by UNICEF (De Neubourg et al., 2012) uses the same dimensions as the Bristol Approach, plus protection from violence and focuses on how the different dimensions overlap for children. Both approaches can therefore be used to measure the "depth" of poverty. A third approach is a child-specific MPI. This index has been developed by Oxford Poverty and Human Development Initiative (OPHI) and is informed by the capabilities approach, with three dimensions of education, health and living standards (Alkire et al., 2017). However, critics have questioned the choice of indicators (Gordon and Nandy, 2012b) and highlighted difficulties in interpreting findings (Roelen, 2017). Lastly, the SDGs stipulate that data, including poverty figures, should be disaggregated by age and gender, which has resulted in the fostering of more global child poverty measurement (see Chzhen, Gordon and Handa, 2018).

Poverty measures, whether monetary or multidimensional, have value in making the scale of the problem visible, working out who is most affected (although this will, of course, differ depending on the measure used (see Main and Bradshaw, 2014; Roelen, 2015)). They also enable the measurement of change over time (making clear, for instance, whether the numbers of children living in poverty are increasing or decreasing in light of social or policy change). Such measures thus have the potential to make important contributions to the work of children's rights scholars and advocates. For instance, such indices can contribute to ESR monitoring through generating data that serves as a basis for advocates to question national policy priorities, such as why countries with similar GDP per capita have different child development outcomes (see, for instance, Bradshaw et al., 2012). Conversely, data-driven measurement approaches pose significant challenges, both conceptually and methodologically 
from a rights perspective. Methodologically, critics contend that such indices do not capture inequality within countries, so progress is achieved by capturing "low hanging fruit" rather than reaching the most marginalised social groups (Ansell, 2017). Conceptually, within economics and in some parts of the international development field, children are viewed as human capital in which it is essential to "invest" in order to develop knowledge, skills and personal characteristics, which can be harnessed for future economic productivity and so contribute to poverty reduction via national economic growth (Cunha and Heckman, 2010). The formation of human capital is central to neoliberal economics and circulates through international development discourses deployed by organizations such as the World Bank (Penn 2002) and has also been used by the likes of UNICEF (2012). There may be strategic advantages to employing such discourses. However as Mestrum (2015: 366) reflects: "one should wonder what happens if the 'return on investment' is to happen or is not the desired one". Children are constructed as objects of development, as adults in the making, valued for future economic contributions, rather than considerations of children's rights and social justice (Morrow and Pells, 2012). This view also constructs children as passive, rather than examining the ways in which children negotiate and contest processes of impoverishment in their daily lives (Unterhalter et al., 2012). Such approaches have roots in colonial projects of civilising and educating the colonialised, and so children (and thereby the nation) are constructed as deficit or stigmatised as 'other', with formal schooling presented as the panacea for a whole range of problems, including poverty (Hopkins and Sriprakash, 2015).

But while it is easy to criticise child poverty scholarship for its failure to engage with child rights, the child rights framework is far from ideal from the perspective of dealing with some of the complexities that arise in relation to children's lived experience of poverty, particularly relative poverty. A consistent finding of child poverty-related research is the stigma experienced by children living in poverty (Ridge, 2004; Sumner, 2010; Walker, 2014). However, while the CRC deals well with stigma that amounts to discrimination in terms of Article 2, CRC it does less well with treatment that falls short of this legal standard. While there are certainly values and principles of child rights that can be used to counter notions of stigma - for instance, respect for human rights dignity and autonomy (see in the context of human rights and poverty more broadly, Sépulveda, 2014) - there has not yet been extensive child rightsspecific work focused on this issue.

A further complex area is the relationship between child and adult poverty. A children's rights approach has been critiqued for a focus on the individual child detached from the familial relations and circumstances in which they are 
living (see, e.g., Vandenhole, 2014; Mestrum, 2015; Brando and Schweiger, 2019). This is not to say that there should not be a focus on children, for reasons discussed above, but rather this has the potential to separate out children and adults, which can then be misappropriated in the services of either neoliberal agenda that sees poverty as an individual failing or greater surveillance of poorer families (see, e.g., Mestrum, 2015; Rosen, 2018).

In summary, in light of the extent of child poverty globally, the over-representation of children among those living in poverty, the lasting impact of poverty on children's lives, and the fact that those working in the fields of child poverty and children's rights have common concerns with regard to improving children's lives, it might seem surprising that there has been such limited engagement between children's rights and child poverty scholarship. At a superficial level, this can perhaps be attributed to the limited consideration of children within debates on human rights, poverty and inequality (Dean, 2007; Balakrishnan and Elson, 2008; Lister, 2004; Townsend, 2009). On a deeper level, however, while rights are sometimes mentioned as a moral rationale for a specific focus on child poverty (White et al., 2002) the conceptual linkages between child poverty and child ESR remain underdeveloped and there are some key theoretical and methodological tensions between the fields of children's rights and some approaches to child poverty.

The current state of CRS on children's ESR and child poverty is very much a "work in progress". There are, however, a number of current areas that the authors view as potential avenues for the extension and refination of such work.

The first of these is the increasing work around the 2030 Agenda for Sustainable Development, which has opened the door for ever-greater interaction between those working in development and ESR-focused child rights scholars (see, e.g., Fenton-Glynn, 2019; Arts 2018; Nolan, 2020 (forthcoming)). It remains to be seen, however, whether this work will adequately interrogate the theoretical and methodological differences between child rights and development approaches - in both the policy and academic contexts. Nor is it clear whether child poverty scholarship will choose to embrace the SDGs to the neglect of child rights as an analytical and prescriptive framework.

Another area which provides scope for a child ESR focus is research centred on the rights impacts and implications of the environment and climate change (see, e.g., Kaime, 2018; Makuch et al., 2019). This is a development to be welcomed, given the frequent co-imbrication of child rights and environmental rights, as well as growing understandings of the complex relationship between 
climate change, child rights and poverty. The recent financial and economic crises served as an important incentive for increased scholarly attention on ESR and poverty; it is only reasonable to expect that the pending environmental crisis will play a similarly catalytic role.

The authors do, however, have concerns that some of the issues that are currently evident in child ESR scholarship - including frequent fuzziness and misunderstanding about the nature and extent of child ESR - being perpetuated in certain areas of scholarship. Well-being is one such area, where children's rights and well-being are either used interchangeably or 'casually paired together' despite their different conceptual, methodological and political foundations (Tisdall, 2015: 807). The aspirational and expansive conceptual framing of well-being may seem attractive given the oft-cited limitations of rights as being minimum standards (see, e.g., Lundy, 2013; Tisdall, 2015). However, the lack of accountability mechanisms associated with the concept of well-being, the absence of a notion of inherent obligation, and well-being's emphasis on outcomes rather than process, raise concerns about the potential dilution of legal commitments to advancing children's interests and status in society.

Finally, further work is needed to assess how a child ESR approach can be used to address the root causes or structures that create, or fail to reduce, poverty. Such work is ever more timely and necessary, given the current global political and economic context. As Townsend (2009: 155) noted, the power of rights is in the shifting of the 'focus of debate from the personal failures of the "poor" to the failures to resolve poverty of macro-economic structures and policies of nation states and international bodies'. A useful example of the shortcomings of CRS from this perspective is the fact that CRS as it stands has only dipped its toe into the pool of economic policy (see, e.g, Stalford, 2019; Reed et al., 2013; Nolan, 2013). This is despite the growing inter-disciplinary conversation about that topic in human rights scholarship more broadly (see, e.g., De Schutter, 2019; Balakrishnan et al., 2016; Nolan et al., 2013) Thus, the challenge for CRS moving forward is how to engage with an ever growing, interdisciplinary field on child poverty so as to work towards addressing the underlying causes and phenomena that exacerbate poverty - a task that will require learning from other disciplines, yet without losing its core "rights" focus and commitment.

\section{Ackowledgement}

The authors would like to thank those who provided information on nonEnglish language child ESR scholarship, including Luciano Bottini Filho, Isaac de Paz González, Horacio Javier Etchichury and Daniela Mendez. They are also 
very grateful to others who have provided helpful feedback, including Paul Dornan and participants at the IJCR UNCRC 3oth Anniversary Conference.

\section{References}

Aarts, K., "Children's Rights and the Sustainable Development Goals" in U. Kilkelly and T. Liefaard (eds.), "Children's Rights and the Sustainable Development Goals", International Law on the Rights of the Child (Switzerland: Springer, 2018): 537.

Alkire, S., Jindra, C., Robles, G. and Vaz, A., "Children's Multidimensional Poverty: Disaggregating the global MPI", OPHI Briefing 46 (Oxford: University of Oxford, 2017).

Alston, P., "Article 32: The Right to Protection from Economic Exploitation" in J. Tobin (ed.), The UN Convention on the Rights of the Child: A Commentary (Oxford: OuP, 2019): 1125 .

Alasuutari, M., "Voicing the child? A case study in Finnish early childhood education" (2014) 21 (2) Childhood 242.

Ansell, N., Children, Youth and Development (London: Routledge, 2016).

Balakrishnan, R., Elson, D. and Heintz, J., Rethinking Economic Policy for Social Justice: The radical potential of human rights (London: Routledge, 2016).

Berthold, S. and Libal, K., "Migrant Children's Rights to Health and Rehabilitation: A Primer for US Social Workers" (2016) 1(2) Journal of Human Rights and Social Work 85 .

Bestard, A., "La asignación universal por hijo y la respuesta judicial al no reconocimiento de los derechos a la alimentación y al cuidado de los niños y niñas discapacitados" in L. Pautassi and C. Zibecchi (eds.), Respuestas Estatales en torno a la Alimentación y al Cuidado. Los casos de los Programas de Transferencia Condicionada de Ingreso y el Plan de Seguridad Alimentaria en la Argentina (Buenos Aires: Grupo de Trabajo Interdisciplinario Derechos Sociales y Políticas Públicas (DSPP). Facultad de Derecho. UBA, 2012).

Bilchitz, D., Poverty and Fundamental Rights: The Justification and Enforcement of SocioEconomic Rights (Oxford, Oxford University Press, 2007).

Bradshaw, J., Chzhen, Y., de Neubourg, C., Main, G., Martorano, B. and Menchini, L., "Relative Income Poverty among Children in Rich Countries", Innocenti Working Paper 2012-01 (UNICEF Innocenti Research Centre, Florence: UNICEF, 2012): www .unicef-irc.org/publications/pdf/iwp_2012_01.pdf.

Brighouse, H., "What Rights (If Any) Do children Have?" in D. Archard and C. Macleod, The Moral and Political Status of Children (Oxford: OuP, 2002) 31.

Bruno, N. and G. Schweiger (eds.), Philosophy and Child Poverty: Reflections on the Ethics and Politics of Poor Children and their Families (Cham, Switzerland, Springer, 2019). 
Byrne, B., "Article 23: Children with Disabilities" in J. Tobin (ed.), The UNConvention on the Rights of the Child: A Commentary (Oxford: oup, 2019) 856.

Byrne B., "Hidden Contradictions and Conditionality: Conceptualisations of Inclusive Education in International Law" (2014) 28 (2) Disability and Society 232.

Chirwa, D., "Combating Child Poverty: The Role of Economic, Social and cultural Rights" in J. Sloth-Neilsen (ed.), Children's Rights in Africa: A Legal Perspective (London: Routledge 2016) 91.

Christie, P., "The complexity of human rights in global times: The case of the right to education in South Africa" (2010) 30 International Journal of Educational Development 3 .

Ceriani Cernadas, P., "The human rights of children in the context of international migration" in W. Vandenhole, E. Desmet, D. Reynaert and S. Lembrechts (eds.), Routledge International Handbook of Children's Rights Studies (London: Routledge, 2015).

Chzhen, Y., Gordon, D. and Handa, S., "Measuring Multidimensional Child Poverty in the Era of the Sustainable Development Goals" (2018) 11(3) Child Indicators Research 707.

Cranston, M., What are Human Rights? (New York, Taplinger Publish Co., 1973).

Croll E., "From the girl child to girls' rights", (2006) 27(7) Third World Quarterly 1285.

Cuhna, F. and Heckman, J., "Investing in our young people", Working Paper 16201 (Cambridge MA: National Bureau of Economic Research, 2010), https://www.nber.org/ papers/w16201.pdf.

Cury, C. and Ferreira, L., "A Judicializaçäo Da Educaçäo" (2009) XIII(45) Revista CEJ 32. de Neubourg, C., Chai, J., de Milliano, M., Plavgo, I. and Wei, Z., "Step-by-Step Guidelines to the Multiple Overlapping Deprivation Analysis (MODA)", Working Paper 2012-10 (UNICEF Office of Research, Florence: UNICEF, 2012).

De Paz González, I., The Social Rights Jurisprudence in the Inter-American Court of Human Rights: Shadow and Light in International Human Rights (Cheltenham: Edward Elgar, 2018).

De Schutter, O., "Public Budget Analysis for the Realization of Economic, Social and Cultural Rights: Conceptual Framework and Practical Implementation" in K. Young (ed.), The Future of Economic and Social Rights (New York: CUP, 2019).

Dean, H., "Social policy and human rights: Re-thinking the engagement", (2007) 7(1) Social Policy \& Society 1.

Dickinson, R, "Parenting a Child with Disabilities: the Intersection of Education and Cultural Perceptions in Southern India" (2018) 3(2) Journal of Human Rights and Social Work 72.

Dixon, R. and M. Nussbaum, “Children's Rights and a Capability Approach: The Question of Special Priority" 97(2011-2012) Cornell Law Review 549. 
Durojaye, E. and Foley, A., "Making a first impression: An assessment of the decision of the Committee of Experts of the African Children's Charter in the Nubian Children communication" (2012) 12(2) African Human Rights Law Journal 564.

Eide, A., Article 27: The Right to an Adequate Standard of Living (Leiden: Martinus Nijhoff, 2006).

Elfström Petersson, K., “Children's participation in preschool documentation practices" (2015) 22(2) Childhood 231.

Etchichury, H., "Planned Differences: Argentina's Universal Child Allowance from a Human Rights Perspective" (2018) 7 Revista de Derecho 199.

Fabre, C., Social Rights under the Constitution - Government and the Decent Life (Oxford, Oxford University Press, 200o).

Feeny, T. and Boyden, J., "Acting in adversity - rethinking the causes, experiences and effects of child poverty in contemporary literature", QEH Working paper series 116 (Oxford, University of Oxford, 2004).

Feinberg, J., "The Child's Right to an Open Future" in J. Feinberg, Freedom and Fulfillment: Philosophical Essays (New Jersey: Princeton University Press, 1992) 76.

Fenton-Glynn, C., (ed.), Children's Rights and Sustainable Development: Interpreting the UNCRC for Future Generation (Cambridge: CUP, 2019).

Flaherty, J., Veit-Wilson, J. and Dornan, P., Poverty: the Facts (London: CPAG, 2004).

Freeman, M., "Why It Remains Important to Take Children's Rights Seriously" in M. Freeman (ed.), Children's Rights: Progress and Perspectives - Essays from the International Journal of Children's Rights (Leiden/Boston: Brill, 2011) 5 .

Garde, A., Byrne, S., Gokani, B. and Murphy, B., "For a Children's Rights Approach to Obesity Prevention: The Key Role of an Effective Implementation of the wHo Recommendations" (2017) 8(2) European Journal of Risk Regulation 327.

Gerber, P., Kyriakakis, J. and O’Byrne, K., “General Comment 16 on State Obligations Regarding the Impact of the Business Sector on Children's Rights: What Is Its Standing, Meaning and Effect?" (2013) 14(1) Melbourne Journal of International Law 93.

Gordon, D. and Nandy, S., "Measuring child poverty and deprivation" in A. Minujin and S. Nandy (eds.), Global Child Poverty and Well-Being: Measurement, concepts, policy and action (Bristol: Policy Press, 2012) 57.

Gordon, D., Nandy, S., Pantazis, C., Pemberton, S. and Townsend, P., Child Poverty in the developing world (Bristol: Policy Press, 2003).

Gray, P., "Youth custody, resettlement and the right to social justice" (2011) 3 Youth Justice $235^{-249 .}$

Griffin, J., On Human Rights (Oxford: Oxford University Press, 2008).

Handsley, E. and Reeve, B., "Holding Food Companies Responsible for Unhealthy Food Marketing to Children: Can International Human Rights Instruments Provide a New Approach?" (2018) 41(2) University of New South Wales Law Journal 449. 
Hanson, K. and Vandaele, A., “Translating Working Children's Rights into International Labour Law" in K. Hanson and O. Nieuwenhuys (eds.), Reconceptualising Children's Rights in International Development: Living Rights, Social Justice, Translations (Cambridge: CUP, 2013) 250.

Hollingsworth, K., “Theorising Children's Rights in Youth Justice: The Significance of Autonomy and Foundational Rights" (2013) 76(6) Modern Law Review 1046.

Hopkins, L. and Sriprakash, A. (eds.), The 'Poor Child': the cultural politics of education, development and childhood (London: Routledge, 2015).

Hulme, D. and McKay, A., "Identifying and Measuring Chronic Poverty: Beyond Monetary Measures?" in N. Kakwani and J. Silber (eds.), The Many Dimensions of Poverty (Basingstoke and New York: Palgrave Macmillan, 2008) 187.

Kaime, T., "Children's Rights and the Environment" in U. Kilkelly and T. Liefaard (eds.), "Children's Rights and the Sustainable Development Goals" International Law on the Rights of the Child (Switzerland: Springer, 2018) 563.

Langford, M. and Khalfiq, U., "Article 26: The Right to Social Security" in J. Tobin (ed.), The UN Convention on the Rights of the Child: A Commentary (Oxford: OuP, 2019) 986.

Lansdown, G. and Tobin, J., "Article 31: The Right to Rest, Leisure, Play Recreation, and Participation in Cultural Life and the Arts" in J. Tobin (ed.), The UN Convention on the Rights of the Child: A Commentary (Oxford: OUP, 2019) 1195.

Larkins, C. et al., "We want to help people see things our way': A rights-based analysis of disabled children's experience living with low income" (London: Children's Commission for England, 2013).

Liebel, M., "Economic and Labour Rights of Children" in J. Todres and S. King (eds.), Oxford Handbook of Children's Rights (New York: Oup, forthcoming 2020).

Liebel, M., "Welfare or Agency: Children's Interests as Foundations of Children's Rights" (2018) 26(4) The International Journal of Children's Rights 597.

Liebel, M., "Protecting the Rights of Working Children instead of Banning Child Labour: Bolivia Tries a New Legislative Approach" (2015) 23(3) The International Journal of Children's Rights 491.

Lister, R., Poverty (Cambridge: Polity, 2004).

Lopes, L., Dutra Asensi, F., da Silva Juni, G., “A judicialização indireta da saúde: um estudo de caso sobre a experiência de Cachoeiro de Itapemirim/ES"(2017) 8(1) Revista Dirieto e Praxis 285.

Lott, N., Making the right to play real through incorporation and implementation, $\mathrm{PhD}$ thesis, University of Nottingham (forthcoming).

Lundy L. "The United Nations Convention on the Rights of the Child and Child WellBeing" in A. Ben Arieh, F. Casas, I. Frones and J. Korbin (eds.), Handbook of Child Well-Being: Theories, Methods and Policies in Global Perspective (Cham, Switzerland, Springer, 2013), 2439. 
Lundy, L. and Tobin, J., "Article 29: The Aims of Education" in J. Tobin (ed.), The UN Convention on the Rights of the Child: A Commentary (Oxford: OUP, 2019) 1195.

Lundy, L., "Voice' is Not Enough: Conceptualisation Article 12 of the United Nations Convention on the Rights of the Child" (2007) 33(6) British Educational Research Journal 927.

Main, G. and Bradshaw, J., "Child Poverty and Social Exclusion: Final Report of 2012 PSE Study", Report on Poverty and Social Exclusion in the UK (York: University of York, 2014).

MacCormick, N., “Children's Rights: A Test-Case for Theories of Rights” (1976) LXII (3) Archiv für Rechts - und Sozialphilosophie 305.

Mahgoub, K., The International Law on the Right of the Child to Survival and Development (Cambridge/Antwerp/Portland: Intersentia, 2015).

Makuch, K., Zaman, S., Aczel, M., “Tomorrow's Stewards: The Case for a Unified International Framework on the Environmental Rights of Children" (2019) 21(1) Health and Human Rights Journal 203.

Matthews, H. and Limb, M., "Defining an Agenda for the Geography of Children: Review and Prospect" 23(1) (1999) Progress in Human Geography 61.

McGrath, S., Education and Development (London: Routledge 2018).

Minujin, A. and Nandy, S. (eds.), Global Child Poverty and Well-Being: Measurement, Concepts, Policy and Action (Bristol: Policy Press, 2012).

Moody, Z. and Darbellay, F., "Studying Childhood, Children, and Their Rights: The Challenge of Interdisciplinarity" (2019) 26(1) Childhood 8.

Morrow, V. and Pells, K., "Integrating children's human rights and child poverty debates: examples from Young Lives in Ethiopia and India", Special Issue on the sociology of human rights, (2012) 46(5) Sociology 906.

Mwambene, L., "Implementing the Girl Child's Right to Education in Selected Countries in Africa" in J. Sloth-Neilsen (ed.), Children's Rights in Africa: A Legal Perspective (London: Routledge 2016) 219.

Nolan, A., "Poverty and Child Rights" in J. Todres and S. King (eds.), Oxford Handbook of Children's Rights Law (New York: OuP, forthcoming 2020).

Nolan, A., "Article 27: The Right to a Standard of Living Adequate for the Child's Development" in J. Tobin (ed.), The UN Convention on the Rights of the Child: A Commentary (Oxford: oup, 2019) 1021.

Nolan, A., "Children's Economic and Social Rights" in U. Kilkelly and T. Liefaard (eds.), International Law on the Rights of the Child (Switzerland: Springer, 2018), 239.

Nolan, A. and Kilkelly, U., “Children's Rights under Regional Human Rights Law: A Tale of Harmonisation?" in Buckley et al. (eds.), Towards Convergence in International Human Rights Law: Approaches of Regional and International Systems (Leiden/ Boston: Brill, 2016) 296. 
Nolan, A., O'Connell, R, \& Harvey, C., (eds), Human Rights and Public Finance: Budgets and the Promotion of Economic and Social Rights (Oxford: Hart, 2013)

Nolan, A., "Economic and Social Rights, Budgets and the Convention on the Rights of the Child" (2013) 21(2) International Journal of Children's Rights 248.

Nolan, A., Children's Socio-economic Rights, Democracy and the Courts (Oxford: Hart Publishing, 2011).

Nyongesa Wabwile, M., Legal Protection of Social and Economic Rights of Children in the developing world: Reassessing International Cooperation and Responsibility (Antwerp: Intersentia, 2010).

O’Brien, C., "'Done Because We Are Too Menny': The Two-Child Rule Promotes Poverty, Invokes a Narrative of Welfare Decadence, and Abandons Children's Rights" (2018) 26(4) International Journal of Children's Rights.

Ó Cathaoir, K.E., A Children's Rights Perspective on Obesogenic Food Marketing (København: Det Juridiske Fakultet, 2017).

Odongo, G., "Caught between Progress, Stagnation and a Reversal of Some Gains: Reflections on Kenya's record in implementing children's rights norm" (2012) 12(1) African Human Rights Law Journal 112.

O'Hare, B, Mfutso Bengo, E., Devakumar, D. and Mfutso Bengo, J., "Survival rights for children: What are the national and global barriers?" (2018) 18 African Human Rights Law Journal 508.

Olinto, P., Beegle, K., Sobrado, C. and Uematsu, H., The state of the poor: where are the poor, where is extreme poverty harder to end, and what is the current profile of the world's poor? (Washington, DC: World Bank, 2013).

O'Mahony, C., Educational Rights in Irish Law (Dublin: Thomson Roundhall, 2006).

Peleg, N., The Child's Right to Development (Cambridge: CuP, 2019).

Peleg, N., "Reconceptualising the Child's Right to Development: Children and the Capability Approach" (2013) 21(3) International Journal of Children's Rights 523.

Pemberton, S., Gordon, D., Nandy, S., Pantazis, C., Townsend. P, “Child Rights and Child Poverty: Can the International Framework of Children's Rights Be Used to Improve Child Survival Rates?" (2007) 4(10) PLoS Mede 307.

Pemberton, S., Gordon, D. and Nandy, S., "Child rights, child survival and child poverty: the debate", in A. Minujin and S. Nandy (eds.), Global Child Poverty and Well-Being: Measurement, Concepts, Policy and Action (Bristol: Policy Press, 2012) 19.

Penn, H., Unequal childhoods: young children's lives in poor countries (London: Routledge, 2005).

Pobjoy, J., "Article 22: The Rights of Refugee Children" in J. Tobin (ed.), The UNConvention on the Rights of the Child: A Commentary (Oxford: OU , 2019) 818.

Reading. R. et al., "Promotion of children's rights and prevention of child maltreatment" (2008) 373 (966o) The Lancet 332. 
Rebell, M., "The Right to Education in the American State Courts" in K. Young (ed.), The Future of Economic and Social Rights (Cambridge, MA: CUP, 2018) 137.

Redmond, G., "Child Poverty and Child Rights: Edging towards a Definition" (2008) 14(1) Journal of Children and Poverty 63.

Reed, H., Elson, D. and Himmelweit, S., "An Adequate Standard of Living: A Child Rights Based Quantitative Analysis of Budgetary Decisions 2010-13: Final Report" (London: Office of the Children's Commission for England, 2013).

Reinbold, G., "Realising Young Children's Right to Health under the Convention on the Rights of the Child: The Promise - and the Reality in Bangladesh and Kenya" (2014) 22 (3) International Journal of Children's Rights 502.

Reynaert, D. and Roose, R., “Children's Rights: A Framework to Eliminate Social Exclusion? Critical Discussions and Tensions" in M. Ruck, M. Peterson-Badali and M.J. Freeman (eds.), Handbook of Children's Rights Global and Multidisciplinary Perspectives (New York: Routledge, 2016) 36.

Reynaert, D., Bouverne-de Bie, M. and Vandevelde, S., "A Review of Children's Rights Literature since the Adoption of the United Nations Convention on the Rights of the Child" (2009) 16(4) Childhood 518.

Ridge, T., Child Poverty and Social Exclusion: From a Child's Perspective (Bristol: Policy Press, 2004).

Riggio, E., "Child friendly cities: good governance in the best interests of the child" (2002) 14(2) Environment \& Urbanization 45.

Roelen, R., Gassmann, F. and de Neubourg, C., "The importance of choice and definition for the measurement of child poverty - the case of Vietnam" (2009) 2(3) Child Indicators Research 245.

Roelen, K., False positives or hidden dimensions: the definition and measurement of child poverty (Maastricht: Boekenplan, 2010).

Roelen, K., 'Reducing all forms of child poverty: the importance of comprehensive measurement' IDS Policy Briefing 98 (Brighton: IDs., 2015).

Roelen, K., "Monetary and Multidimensional Child Poverty: A Contradiction in Terms?" (2017) 48 Development and Change 502.

Rosen, R. "Poverty and Family Troubles: Mothers, Children, and Neoliberal 'Antipoverty' Initiatives“ (2019) 40(16) Journal of Family Issues 2330.

Sanghera, J. et al., "Human Rights in the New Global Strategy" (2015) 351 British Medical Journal h4184.

Sépulveda, M., From Undeserving Poor to Rights-holder: A Human Rights Perspective on Social Protection Systems (Oxfordshire: Development Pathways, 2014).

Shue, H., Basic Rights: Subsistence, Affluence and US Foreign Policy, 2nd edn., (Princeton, Princeton University Press, 1996).

Simpson, M., "Social Rights, Child Rights, Discrimination and Devolution: Untangling the Web" (2018) 40(1) Journal of Social Welfare and Family Law 3. 
Sloth-Nielsen J., “The Protection of Children's Economic, Social and Cultural Rights under the African Children's Charter" in D. Chirwa and L. Chenwi (eds.), The Protection of Economic, Social and Cultural Rights in Africa: International, Regional and National Perspectives (Cambridge: Cambridge University Press, 2016) 155.

Sloth-Nielsen, J., “The Child's Rights to Social Services, the Right to Social Security, and Primary Prevention of Child Abuse: Some Conclusions in the Aftermath of Grootboom" (2001) 17 South African Journal on Human Rights 210.

Smyth, C., "Migration, Refugees and Children's Rights" in U. Kilkelly and T. Liefaard (eds.), International Law on the Rights of the Child (Switzerland: Springer, 2018) 421.

Spronk-Van der Meer, S., The Right to Health of the Child (Cambridge/Antwerp/Portland: Intersentia, 2014).

Stalford, H., "The Price is Rights!: Cost benefit analysis and the resourcing of children's services" (2019) 99(c) Children and Youth Services Review 395.

Sumner, A., "Child poverty, well-being and agency: What does a '3-D well-being' approach contribute?" (2010) 22 Journal of International Development 1064.

Takeuchi, L., "Intra-household inequalities in child rights and wellbeing A barrier to progress?", oDI Development Progress Research Report 2 (London: ODI, 2015).

Tisdall, K., "Children's Rights and Children's Wellbeing: Equivalent Policy Concepts?" (2015) 44(4) Journal of Social Policy 807.

Tobin, J., "Justifying Children's Rights" (2013) 21(3) International Journal of Children's Rights 395 .

Tobin, J., "Article 24: The Right to Health" in J. Tobin (ed.), The UN Convention on the Rights of the Child: A Commentary (Oxford: OUP, 2019) 902.

Townsend P., (ed.), Building Decent Societies. Rethinking the Role of Social Security in Development (Geneva: ILO, Palgrave Macmillan, 2009).

World Bank Group and UNICEF, "Ending extreme poverty: a focus on children", Briefing note (New York/Washington: UNICEF and World Bank Group, 2016).

UNICEF, The State of the World's Children 2005: Childhood under Threat (New York, UNICEF, 2005).

UN Committee on the Rights of the Child, General Comment No. 19 on public budgeting for the realization of children's rights (art. 4), UN Doc. CRC/C/GC/19 (2016).

UN Office of the High Commissioner Human Rights (онснR), Final Draft of the Guiding Principles on Extreme Poverty and Human Rights Submitted by the Special Rapporteur on Extreme Poverty and Human Rights, Magdalena Sépulveda Carmona, UN Doc. A/HRC/21/39 (18 July 2012).

UN Office of the High Commissioner Human Rights (OHCHR), Principles and Guidelines for a Human Rights Approach to Poverty Reduction Strategies, UN Doc. HR/ PUB/o6/12 (2006), available at: http://www.ohchr.org/Documents/Publications/ PovertyStrategiesen.pdf. 
UN Office of the High Commissioner Human Rights (OHCHR), Human Rights and Poverty Reduction, A Conceptual Framework, UN Doc. HR/PUB/04/1 (2004), available at: http://www2.ohchr.org/english/issues/poverty/docs/povertyE.pdf.

Unterhalter, E., Yates, C., Makinda, H. and North, A. "Blaming the poor: constructions of marginality and poverty in the Kenyan education sector" (2012) 42(2) Compare:A Journal of Comparative And International Education 213.

Vandenhole, W., "Economic, Social and Cultural Rights in the CRC: 'Is There a Legal Obligation to Cooperate Internationally for Development?'” (2009) 17 International Journal of Children's Rights 23.

Vandenhole, W., "Child Poverty and Children's Rights: An Uneasy Fit?", (2013) 22 Mich. St. Int'l L. Rev. 6og). https://digitalcommons.law.msu.edu/ilr/vol22/iss2/6.

Veriavaa, F. and Skelton, A., "The Right to Basic Education: A Comparative Study of the United States, India and Brazil - research", 35(1) South African Journal of Human Rights (2019) 1.

Veerman, P., The Rights of the Child and the Changing Image of Childhood (Dordrecht, Martinus Nijhoff Publishers, 1992) 25.

Verheyde, M., Article 28: The Right to Education (Leiden: Martinus Nijhoff, 2006).

Waldron, J., "Duty-bearers for Positive Rights" (2014) NYU School of Law Public Law and Legal Theory Research Paper Series Working Paper 14.

Waldron, J., "Socioeconomic Rights and Theories of Justice" 48 San Diego L. Rev. 773 (2011).

Walker, R., The Shame of Poverty (Oxford: Oxford University Press, 2014).

Warwick, B., "Unwinding Retrogression; Conflicting Concepts and Patchy Practice" (2019) 19(3) Human Rights Law Review 467.

World Bank, Poverty and Shared Prosperity 2018: Piecing Together the Poverty Puzzle (Washington, DC: World Bank, 2018). 